\title{
Panabokke C.R. (2007) Groundwater Conditions In Sri Lanka: a geomorphic perspective. National Science Foundation of Sri Lanka, 47/5, Maitland Place, Colombo 7
}

\author{
Ananda Gunatilaka \\ No 10, Thumbovila, Piliyandala.
}

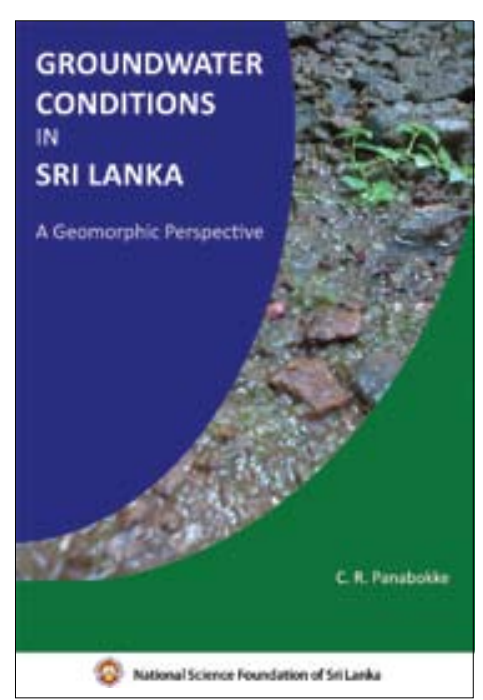

Water is the most precious, cheapest and the leastregulated natural resource in the world. It is a renewable resource and there are no substitutes for water. Yet, accessibility to cheap and clean water is destined to be the defining crisis of the $21^{\text {st }}$ century. Water security is defined as the availability and accessibility of communities to cheap and clean water for drinking, sanitation, health and other human activities. The World Bank has estimated that only 10 percent of Sri Lanka's rural population has accessibility to treated, tap-delivered water; every fifth person relies on untreated water for drinking and that almost 30 percent has no access to sanitary latrines. A major part of the rural and suburban population is still dependent on groundwater from wells for their daily requirements. Also, increasingly, groundwater is now being exploited for agricultural activities and requirements. Sri Lanka's groundwater reserves have been estimated at $\sim 78,000$ million cubic metres and are distributed within six major aquifer types. The World Health Organization (WHO) estimates that 1000 cubic metres / capita / year is the absolute basic minimum requirement (bmr) for human activities. Water scientists also emphasize that $1750 \mathrm{cu} . \mathrm{m} / \mathrm{capita} / \mathrm{year}$ is the global water-stress threshold (gwst), below which communities are under permanent or seasonal water-stress conditions.
The per capita total water availability in Sri Lanka is estimated at $\sim 2800$ cubic metres per year, which suggests that Sri Lanka is adequately endowed with water resources for daily requirements and that there is no serious cause for concern. However, three districts (Colombo, Puttalam and Jaffna) are already below the bmr and this is expected to rise to six districts (with Kurunegala, Gampaha and Kandy) by 2025 . The per capita water availability will also decrease with time and increase in population and improvement of living standards. In fact, increases in GDP, per capita incomes and better living standards are reflected in the increasing daily water requirements in Sri Lanka (as elsewhere). So, there will be an impending water crisis in the future due to unequal distribution and accessibility to water across the country.

It is with the above facts in mind that I started reading and reviewing the book on "Groundwater Conditions in Sri Lanka"by Vidya Jyothi C.R. Panabokke, who is one of Sri Lanka's most venerable scientists, still writing at the ripe old age of 82 . I will not dwell upon his various research activities, achievements and the vital positions he held in the public service of Sri Lanka, except to mention that he was Head of the Land Use Division, Department of Irrigation (1969-1974) and Deputy Director of Research (1974-1979) as well as Director of the Department of Agriculture (1979-1982), a unique career, in which he had deep insights into both water science and soil science (in irrigation and agriculture) and attendant issues. Consequently, from soils to water, he had provided leadership to land and water management research in Sri Lanka for over 25 years.

The book consists of 12 Chapters. The first chapter gives a general overview of the occurrence and 
movement of groundwater (flow) in the various aquifer types in Sri Lanka and briefly mentions the concept of groundwater quality and its significance. This forms the background to the book. The second chapter is most appropriate as it gives a very informative run-down of the most seminal research publications on groundwater investigations over the past 85 years, highlighting especially the pioneering studies of C.H.L Sirimanne of the Geological Survey Department (GSD), who laid down the basic framework for groundwater studies in Sri Lanka. The abstracts of these papers are reproduced in this chapter and are a most useful addition to the book and for any water scientist intending to read the history of hydrological studies in Sri Lanka.

The periods prior to and after the setting up of the National Water Supply and Drainage Board, the Groundwater Exploration Division within the Irrigation Department (ID) headed by Sirimanne and the Water Resources Board (WRB) in 1978 are landmarks in groundwater investigations in the country. The responsibility for such studies was eventually passed on from the GSD to the ID and to the WRB. Today, the mandated authority for water investigations rests with the WRB. Preparation of a bibliography up to the year 2000 by the WRB, a Groundwater Database of the two main state agencies responsible for water affairs, thematic research papers on groundwater, preparation of groundwater maps $(1968 ; 1973)$ are all essential reading for water scientists.

Chapters 3 to 10 form the core of the book with a no frills geomorphic approach to the various aquifer types in Sri Lanka and their hydrological potential. Depending on how you classify them, there are 6 to 8 main aquifer types. There are no demanding hydrological flow equations, pump test and recharge data and other statistical tables to distract the reader from the author's intended geomorphic perspective. The aquifer types and their distributions are dealt with under, a) shallow karstic aquifer of the Jaffna Peninsula; b) confined and semi-confined deep aquifers of the northwestern sedimentary formations; c) metamorphic hard-rock region aquifers of the Dry Zone; d) shallow, coastal sand aquifers; e) alluvial aquifers; f) laterite aquifers and g) metamorphic hard-rock region aquifers of the Wet Zone. Each aquifer type, with examples, is dealt with under previous studies; aquifer properties; present utilization and potential threats and brings into focus the problem of groundwater management issues. These eight chapters are essential reading for anyone initiated in the basic sciences and interested in groundwater issues. Chapter 11 on the "Springs of Sri Lanka" is a short six pages and appears very much as an afterthought by the author. Nevertheless, it is a useful record for the uninitiated reader. The ultimate objective of this book is summed up and discussed in Chapter 12 and emphasizes the critical concepts of groundwater quality, sustainable groundwater use and the need for water quality monitoring. The several appendices at the end of the book are a welcome addition and a very useful effort and will be of much help to the readers. The glossary and index is adequate.

The reviewer feels that in this day and age of computer graphics, the diagrams could have been drafted better. Also, GIS-maps could have better illustrated the links between groundwater aquifers, geology, soils, rainfall distributions and also population densities at district level. I would have also liked to see a paragraph or page on the impact of the 2004 Tsunami on the fate of the vital shallow coastal sand aquifer, which has still not fully recovered even three years after the eventbringing into question the long term sustainability and its vulnerability due to population increases and coastal hazards. Still, these are minor drawbacks in an otherwise excellent compilation.

The new generation of hydrologists should now embark upon quantifying the resource potential and water availability in each of the aquifer types described in this book, engage in quantitative groundwater modeleing and continuous reserve estimation and on a framework of projected future water demands in relation to the expected short-term climate change. Can the water scientists ensure that there is integrated water resources management and distribution in Sri Lanka and that per capita water availability is kept above the stressthreshold of 1750 cu.m/yr, through the conjunctive use of both surface and groundwater?

I enjoyed reading this timely publication by Panabokke. It is written in very simple and readable language with no obfuscation of the subject matter. It is an invaluable, non-quantitative compilation of a scientist with over 50 years experience in soils and water. I congratulate the author for the dedicated effort and for spending many valuable years of retirement time to complete publication. The Rs. 750 price-tag is money well spent and hope it will not be excessive in these inflation-ridden times. Anybody interested in groundwater should have a copy on his or her shelf. The National Science Foundation, celebrating the $40^{\text {th }}$ anniversary of its existence this year (2008), and whose first Secretary-General was also Dr. Panabokke, is to be commended for sponsoring this publication, which deals with our most precious natural resource. 